\title{
Efek Analgesik Ekstrak Etanol Zingiber cassumunar Roxb. pada Mencit dengan Metode Writhing Test
}

\section{The Analgesic Effect of Zingiber cassumunar Roxb. Ethanol Extract on Mice using Writhing Test Method}

\author{
Qonita Bajuber $^{1 *}$, Danti Nur Indiastuti², Edward Kusuma ${ }^{3}$ \\ ${ }^{1}$ Profesi Kedokteran, ${ }^{2}$ Departemen Farmakologi, ${ }^{3}$ Departemen Anestesiologi dan Reanimasi, \\ Fakultas Kedokteran, Universitas Airlangga \\ *Corresponding author: qonitabjbr@yahoo.com
}

\begin{abstract}
Abstrak
Penelitian bertujuan untuk menguji efek analgesik ekstrak etanol Zingiber cassumunar Roxb. pada mencit yang diinduksi dengan asam asetat. Penelitian ini merupakan penelitian eksperiment posttest only control design, menggunakan metode writhing test. Sampel penelitian terdiri dari 25 mencit terbagi dalam tiga kelompok perlakuan ekstrak Zingiber cassumunar Roxb.; P1, P2, dan P3, dengan masing-masing dosis 100 $\mathrm{mg} / \mathrm{kgBB}, 200 \mathrm{mg} / \mathrm{kgBB}, 400 \mathrm{mg} / \mathrm{kgBB}$, kelompok kontrol negatif aquades (K-), serta kelompok kontrol positif aspirin $(\mathrm{K}+)$. Hasil penelitian menunjukkan bahwa (P1) dan (P2) signifikan menurunkan jumlah geliat pada mencit dibandingkan (K-) ( $<<0,05)$, dengan persentase penurunan jumlah geliat sebesar 49,53\% dan 57,01\%, sedangkan (P3) tidak menunjukkan aktivitas analgesik. Ekstrak Zingiber cassumunar Roxb. dosis $100 \mathrm{mg} / \mathrm{kgBB}$ dan $200 \mathrm{mg} / \mathrm{kgBB}$ tidak memiliki perbedaan yang signifikan terhadap $(\mathrm{K}+)$ untuk mengurangi rasa nyeri.
\end{abstract}

Kata kunci: rimpang, Zingiber cassumunar Roxb., ekstrak etanol, analgesik, uji geliat

\section{Abstract}

This study aimed to measure the analgesic effect of ethanol extract of Zingiber cassumunar Roxb. rhizome on mice induced by acetic acid. This study was an experimental study with post-test only control design using writhing test method. The sample of the study consisted of 25 mice which were divided into 3 treated groups of Zingiber cassumunar Roxb. extract; P1, P2, and P3, with dosage of $100 \mathrm{mg} / \mathrm{kgBW}, 200 \mathrm{mg} / \mathrm{kgBW}$, $400 \mathrm{mg} / \mathrm{kgBW}$ respectively, a negative control of distilled water (K-), and a positive control of aspirin (K+). The result showed that $(\mathrm{P} 1)$ and $(\mathrm{P} 2)$ significantly decreased the number of the writhing in mice compared to (K-) ( $p<0,05)$, with percentage of writhing protection of 49,53\% and 57,01\%, while (P3) group did not show any analgesic activity. Zingiber cassumunar Roxb. extract of $100 \mathrm{mg} / \mathrm{kgBW}$ and $200 \mathrm{mg} / \mathrm{kgBW}$ showed the insignificant result of pain inhibition compared to the $(\mathrm{K}+)$.

Key words: rhizome, Zingiber cassumunar Roxb., ethanol extract, analgesic, writhing test

Received: 24 Oktober 2019

Revised: 31 Oktober 2019

Accepted: 25 November 2019

\section{PENDAHULUAN}

Nyeri merupakan sensasi emosional tidak menyenangkan yang ditunjukkan pada saat terjadi kerusakan jaringan (International Association for the Study of Pain, 2017). Berdasarkan studi, didapatkan data bahwa ratarata prevalensi nyeri kronis di dunia mencapai angka yang cukup tinggi, yaitu 30,3\% sehingga hal ini patut diperhatikan (Elzahaf dkk, 2012).

Rangsangan nyeri dibedakan menjadi empat jenis, berupa rangsangan kimia, mekanik, panas, dan dingin (Guyton dan Hall, 2011). Mekanisme terjadinya nyeri dimulai pada saat saraf perifer menerima stimulus hingga ambang batas tertentu (threshold) dari luar tubuh. Stimulus tersebut memicu sintesis prostaglandin (PG) serta beberapa senyawa lain oleh membran fosfolipid sel perifer, kemudian stimulus ditransduksikan ke traktus spinotalamikus dan ditransmisikan ke sistem saraf pusat agar dapat diproyeksikan menjadi rasa nyeri (Golan dkk, 2017).

Selama ini efek analgesik didapatkan dari penggunaan obat jenis opioid yang bekerja di 
sistem saraf pusat, serta obat anti inflamasi nonsteroid (OAINS) yang bekerja di sistem saraf perifer. Salah satu jenis OAINS yaitu aspirin, memiliki efek sebagai antipiretik, anti-inflamasi dan analgesik (Hitner dan Nagle, 2012). Penggunaan obat analgesik menunjukkan angka yang tinggi, namun obat-obat tersebut memiliki efek samping yang tidak diinginkan, seperti gangguan pada saluran cerna, ginjal, dan hati, sehingga masyarakat mulai mencari alternatif obat-obat tradisional sebagai pengganti. Salah satu yang banyak digunakan yaitu kelompok jahe (Pudjiastuti, 1999; Setyawati, 2012).

Zingiber cassumunar Roxb. merupakan tanaman yang biasa dikenal dengan nama bangle dan digunakan sebagai obat tradisional (Arafah dkk, 2004). Tanaman ini merupakan salah satu jenis dari kelompok jahe, serta memiliki efek analgesik karena beberapa kandungan di dalamnya yang bekerja menurunkan prostaglandin E2 (PGE2) dan ekspresi siklooksigenase-2 (COX-2) (Aupaphong dkk, 2012). Namun penggunaannya secara luas masih sedikit dipelajari, sehingga guna membuktikan manfaat analgesik dari herbal ini dibutuhkan obat pembanding dan pengujian yang salah satunya dengan menggunakan metode writhing test, yaitu metode yang digunakan untuk menginduksi nyeri saraf perifer dengan menginjeksikan zat iritan seperti asam asetat ke intraperitoneal, menyebabkan respon nyeri pada hewan coba berupa refleks geliat (Milind dan Monu, 2012).

Penelitian ini bertujuan untuk mengetahui efek analgesik ekstrak etanol Zingiber cassumunar Roxb. serta dosis efektif yang dapat digunakan dalam mengurangi rasa nyeri.

\section{METODE PENELITIAN}

\section{Uji Ethical Clearance}

Eksperimen dilakukan di Laboratorium Farmakologi Fakultas Kedokteran dengan persetujuan Komite Etik Penelitian Kesehatan Fakultas Kedokteran Universitas Airlangga dalam surat keterangan kelaikan etik nomor 217/EC/KEPK/FKUA/2019.

\section{Alat dan Bahan}

Alat yang digunakan yaitu instrumen ekstraksi rimpang Zingiber cassumunar Roxb., serta instrumen uji analgesik writhing test, yaitu terdiri dari spuit $1 \mathrm{cc}$, kandang, stopwatch, counter, dan catatan.

Bahan utama pada penelitian uji efek analgesik ini adalah rimpang Zingiber cassumunar Roxb. yang didapatkan dari UPT Materia Medica Batu, Jawa Timur. Bahan-bahan lain yang digunakan yaitu etanol $70 \%$, aquades, CMC-Na, dan aspirin.

\section{Ekstraksi}

Rimpang Zingiber cassumunar Roxb. diekstraksi dengan metode maserasi. Metode ekstraksi dimulai dengan maserasi 200 gram serbuk rimpang Zingiber cassumunar Roxb. yang sudah kering dan halus dengan menggunakan 1,5 liter etanol $70 \%$ pada suhu kamar selama 2-3 hari, kemudian disaring. Residu dimaserasi ulang dengan $500 \mathrm{ml}$ etanol $70 \%$ pada suhu kamar selama 2 hari, lalu disaring dan filtrat dipekatkan dengan rotary evaporator pada suhu $50^{\circ} \mathrm{C}$ hingga diperoleh ekstrak kental. Ekstrak kental ditimbang dan disuspensi dengan CMC-Na dan Aquades sesuai dosis yang telah ditentukan.

\section{Hewan Percobaan}

Pada penelitian ini, mencit yang digunakan berjenis kelamin jantan, berusia 2-3 bulan, dan berberat badan 25-35 gram. Mencit diaklimatisasi selama 1 minggu agar dapat menyesuaikan dengan kondisi pada laboratorium. Apabila berat badan turun lebih dari $10 \%$, sakit, atau mati, maka mencit dikeluarkan dari sampel penelitian.

\section{Perlakuan}

Sebanyak 25 mencit (Mus musculus) dikelompokkan ke dalam 5 kelompok perlakuan yang dibagi secara acak, yaitu : (K-) kelompok kontrol negatif dengan perlakuan diberi aquades $25 \mathrm{~mL} / \mathrm{kgBB}$; (P2) diberi ekstrak Zingiber cassumunar Roxb. dosis $100 \mathrm{mg} / \mathrm{kgBB}$; (P3) diberi ekstrak Zingiber cassumunar Roxb. dosis 200 mg/kgBB; (P4) diberi ekstrak Zingiber 
cassumunar Roxb. dosis $400 \mathrm{mg} / \mathrm{kgBB}$; (P5) kelompok positif aspirin dosis $91 \mathrm{mg} / \mathrm{kgBB}$.

Setiap hewan coba diberi per oral masingmasing sampel sesuai dengan jenis dan dosis yang telah ditentukan. 30 menit setelah pemberian sampel, mencit diinduksi dengan injeksi intraperitoneal asam asetat $1 \%$ volume 5 $\mathrm{mL} / \mathrm{kgBB}$, kemudian jumlah geliat mulai diamati dan dihitung 5 menit setelahnya. Frekuensi geliat diukur setiap 10 menit selama satu jam. Geliat ditandai dengan respon berupa refleks melengkungkan punggung, ekstensi kaki belakang, serta kontraksi abdominal.

\section{Analisis}

Data yang terkumpul dianalisis dengan Uji normalitas Saphiro-wilk dan uji homogenitas Lavene, kemudian dilanjutkan uji komparasi one-way ANOVA, serta uji posthoc beda nyata kecil (LSD) untuk mengetahui signifikansi perbedaan pada masing-masing kelompok.

\section{HASIL DAN PEMBAHASAN}

Metode ekstraksi yang digunakan yaitu etanol, karena sifatnya yang merupakan pelarut polar, sehingga diharapkan dapat meningkatkan efektivitas pengikatan kadar flavonoid yang juga bersifat polar dan memiliki efek analgesik (Suryani dkk, 2016). Selain itu, etanol aman digunakan baik pada mencit sebagai hewan coba, maupun pada manusia (Astuti, 2013).

Uji geliat dipilih karena merupakan uji yang paling banyak digunakan untuk mengukur respon aktivitas analgesik pada saraf perifer dengan menggunakan rangsangan kimiawi berupa injeksi asam asetat intraperitoneal. Asam asetat digunakan karena dapat menyebabkan kerusakan jaringan sekitar untuk sementara waktu, sehingga rangsangan akan dibawa ke otak dan diinterpretasikan sebagai rasa nyeri perifer oleh serabut saraf tipe C (Guyton dan Hall, 2011). Hasil dari penelitian ini menunjukkan efek ekstrak Zingiber cassumunar Roxb. hanya sebatas penggunaanya dalam mengurangi rasa nyeri perifer. Selanjutnya, guna mengetahui efek penggunaan ekstrak pada nyeri sentral, perlu dilakukan jenis uji lainnya, seperti uji tail-flick dan hot-plate yang memanfaatkan rangsangan panas untuk menginduksi nyeri sentral (Das dkk, 2017).

Hasil uji efek analgesik dari ekstrak Zingiber cassumunar Roxb. terhadap mencit didapatkan dari 5 kelompok perlakuan dengan rata-rata dan standar deviasi hasil geliat yang ditunjukkan pada Tabel 1.

Berdasarkan tabel tersebut dapat dilihat bahwa efek kerja ekstrak Zingiber cassumunar Roxb. pada P1 dan P2 sudah dimulai sejak menit ke 0-10 dengan adanya perbedaan jumlah geliat dibandingkan dengan kelompok K-, begitu pula dengan kelompok $\mathrm{K}+$, terlihat penurunan jumlah geliat dimulai sejak 10 menit pertama. Hal ini menunjukkan bahwa kerja ekstrak dosis 100 $\mathrm{mg} / \mathrm{kgBB}, 200 \mathrm{mg} / \mathrm{kgBB}$, serta aspirin sebagai analgesik sudah dimulai sejak 30-40 menit dari waktu pemberian obat pada mencit. Hasil ini sejalan dengan onset kerja aspirin yang dimulai setelah 20 menit dari waktu pemberian obat (Cooper dkk, 2012).

Selain itu, pada gambar 1 terdapat persen proteksi geliat yang dihitung menggunakan rumus $100-\left[\left(\frac{P}{K}\right) x 100\right] \%$, dengan $\mathrm{P}=$ Jumlah geliat kumulatif setiap kelompok perlakuan dan $\mathrm{K}=$ Jumlah geliat kumulatif kelompok K-. Persen proteksi geliat dihitung untuk mengetahui dan membandingkan aktifitas analgesik pada masing-masing kelompok dibandingkan dengan kelompok K-

Berdasarkan persentase proteksi geliat pada gambar 1, terlihat bahwa persen inhibisi tertinggi terdapat pada $\mathrm{P} 2$, tidak berbeda jauh dengan P1 dan $\mathrm{K}+$, yaitu masing-masing $57.01 \%, 49.53 \%$ dan $53.27 \%$, sedangkan efek proteksi paling rendah terdapat pada P3 dengan proteksi geliat hanya sebesar $2.80 \%$. Selain itu, pada uji komparasi one-way ANOVA yang telah dilakukan, hasilnya menunjukkan terdapat perbedaan yang signifikan antar kelompok ( $\mathrm{p}<0.05)$. Kemudian, pada uji posthoc, P1 dan P2 tidak memiliki perbedaan yang bermakna terhadap kelompok $\mathrm{K}+$, sehingga penggunaan ekstrak dosis $100 \mathrm{mg} / \mathrm{kgBB}$ dengan dosis 200 $\mathrm{mg} / \mathrm{kgBB}$ memiliki efek yang sama dengan penggunaan aspirin dalam mengurangi rasa nyeri pada mencit. 
Tabel 1. Rata-rata dan standard deviasi geliat mencit setelah diinduksi dengan asam asetat

\begin{tabular}{|c|c|c|c|c|c|c|c|}
\hline & \multicolumn{6}{|c|}{$\begin{array}{c}\text { Rata-rata dan standar deviasi geliat mencit } \\
\text { Menit ke- }\end{array}$} & \multirow{2}{*}{$\begin{array}{l}\text { Rata-rata } \\
\text { kelompok }\end{array}$} \\
\hline & 0-10 & 11-20 & $21-30$ & $31-40$ & 41-50 & $51-60$ & \\
\hline $\mathbf{K}+$ & $3.20 \pm 2.17$ & $3.20 \pm 3.11$ & $2.00 \pm 2.00$ & $1.20 \pm 1.64$ & $0.80 \pm 0.84$ & $0.00 \pm 0.00$ & $08.67 \pm 2.67$ \\
\hline K- & $4.20 \pm 1.92$ & $5.80 \pm 1.48$ & $4.80 \pm 1.64$ & $3.40 \pm 1.50$ & $1.40 \pm 1.14$ & $1.80 \pm 2.39$ & $17.83 \pm 3.51$ \\
\hline P1 & $2.60 \pm 1.52$ & $3.20 \pm 2.05$ & $1.60 \pm 2.07$ & $2.20 \pm 1.79$ & $1.20 \pm 1.09$ & $0.20 \pm 0.45$ & $09.00 \pm 2.24$ \\
\hline $\mathbf{P 2}$ & $2.20 \pm 1.30$ & $3.00 \pm 1.22$ & $1.60 \pm 2.07$ & $1.20 \pm 1.09$ & $1.00 \pm 1.73$ & $0.20 \pm 0.45$ & $07.67 \pm 1.99$ \\
\hline P3 & $5.00 \pm 0.71$ & $5.80 \pm 1.09$ & $4.80 \pm 1.48$ & $2.20 \pm 1.09$ & $2.20 \pm 2.17$ & $1.60 \pm 1.95$ & $17.33 \pm 1.91$ \\
\hline
\end{tabular}

\section{Persentase Proteksi Geliat Mencit}

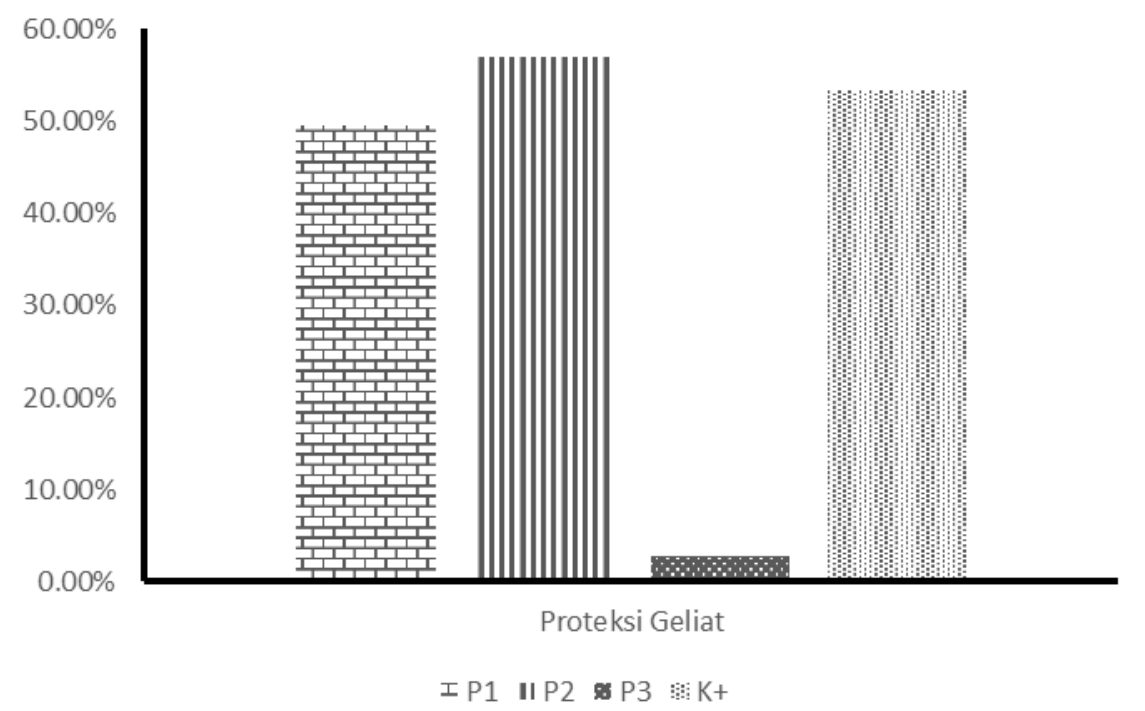

Gambar 1. Persentase proteksi geliat mencit

Penggunaan dosis $200 \mathrm{mg} / \mathrm{kgBB}$ lebih disarankan karena mempertimbangkan besar persentase proteksi geliat yang ditunjukkan, serta rendahnya kemungkinan terdapatnya efek samping. Efek samping penggunaan ekstrak Zingiber cassumunar Roxb. telah diuji pada penelitian sebelumnya, masing-masing mencit diberi ekstrak dengan dosis mencapai 1.250 $\mathrm{mg} / \mathrm{kgBB} / \mathrm{hari}$, hasilnya tidak menunjukkan adanya efek samping jangka pendek maupun jangka panjang terhadap mencit (Koontongkaew dkk, 2014). Penelitian lain juga menyebutkan bahwa percobaan penggunaan ekstrak Zingiber cassumunar Roxb. pada manusia selama empat minggu dengan dosis $850 \mathrm{mg} /$ hari menunjukkan bahwa penggunaannya aman dan tidak terdapat efek samping (Kato dkk, 2018).

Hasil dari penelitian ini sejalan dengan penelitian-penelitian yang telah dilakukan sebelumnya. Efek Zingiber cassumunar Roxb. telah diteliti dengan metode writhing test menggunakan ekstraksi dichloromethanol dosis $200 \mathrm{mg} / \mathrm{kgBB}$ pada mencit, hasilnya menunjukkan bahwa terdapat efek analgesik yang signifikan pada penggunaan ekstrak, dibuktikan dengan jumlah geliat yang nilainya menurun hingga 55.48\% (Koparde dan Magdum, 2018). Penelitian lain yang sejenis yaitu pada penggunaan Zingiber cassumunar Roxb. dalam bentuk cream yang dilakukan oleh Manimmanakorn dkk tahun 2016, hasilnya menunjukkan bahwa penggunaan cream konsentrasi $14 \%$ lebih baik daripada konsentrasi $7 \%$ dalam mengurangi kekakuan dan nyeri otot setelah melakukan olahraga. Hasil ini berkaitan dengan adanya senyawa aktif yang diduga berperan paling dominan dalam menurunkan respon nyeri pada penggunaan ekstrak etanol Zingiber cassumunar Roxb., yaitu flavonoid. Flavonoid terbukti bekerja menurunkan rasa 
nyeri dengan cara menghambat produksi prostaglandin E2 melalui penurunan enzim COX-2 (Hämäläinen dkk, 2011).

\section{KESIMPULAN}

Ekstrak Zingiber cassumunar Roxb. memiliki efek analgesik. Dosis ekstrak yang efektif mengurangi rasa nyeri yaitu sebesar 100 $\mathrm{mg} / \mathrm{kgBB}$ dan $200 \mathrm{mg} / \mathrm{kgBB}$, sedangkan dosis $400 \mathrm{mg} / \mathrm{kgBB}$ tidak memiliki efek analgesik.

\section{UCAPAN TERIMA KASIH}

Terima kasih kepada Laboratorium Farmakologi Fakultas Kedokteran Universitas Airlangga yang telah memfasilitasi pelaksanaan penelitian ini.

\section{DAFTAR PUSTAKA}

Arafah, E., Muchtadi, D., Zakaria, F.R., Wresdiyati, T., Sidik. 2004. Protective Effect of Bangle (Zingiber cassumunar Roxb.) Rhizome Extract on CCL4-Induced Liver Damage of Rats. Indon. Assoc. Food Technol., 15(3), 214-220.

Astuti, T.B., 2013. Uji Aktivitas Antimikroba Ekstrak Etanol 70\% Rimpang Bangle (Zingiber purpureum Roxb.) terhadap Bakteri Staphylococcus aureus ATCC 25925 dan Jamur Microsporum canis secara in vitro. [Skripsi]. Fakultas Kedokteran dan Ilmu Kesehatan. UIN Syarif Hidayatullah Jakarta.

Aupaphong, V., Ayudhya, T.D.N., Koontongkaew, S. 2012. Inhibition of Lipopolysaccharide-induced Expression of Cyclooxygenase-2 by Zingiber cassumunar Roxb. Constituents in Human Dental Pulp Cells. J. Med. Plants Res., 7(33), 2451-2458.

Cooper, S.A., Voelker, M. 2012. Evaluation of Onset Pain Relief from Micronized Aspirin in a Dental Pain Model. Inflammopharmacol., 20(4), 233-242.
Das, M., Gohain, K., Das, S. 2017. Evaluation of Central and Peripheral Analgesic Activities of Solanum melongena Ethanolic Leaf Extract in Experimental Animals. Int. J. Pharm. Sci. Res., 22, 1168-1172.

Elzahaf, R.A, Tashani, O.A., Unsworth, B.A., Johnson M.I. 2012. The prevalence of chronic pain with an analysis of countries with a Human Development Index less than 0.9 : a systematic review without metaanalysis. Curr. Med. Res. Opinion, 28(7), 1221-1229.

Golan, D. E., Armstrong, E.J., Armstrong, A.W. 2017. Principles of Pharmacology. 2nd ed. Philadelphia: Lippincott Williams \& Wilkins, p264-267.

Guyton, A.C., Hall, J.E. 2011. Guyton dan Hall Buku Ajar Fisiologi Kedokteran. 12th ed. Singapore: Elsevier Saunders, p583-585.

Hämäläinen, M., Nieminen, R., Asmawi, M., Vuorela, P., Vapaatalo, H., Moilanen, E. 2011. Effects of Flavonoids on Prostaglandin E2 Production and on COX-2 and mPGES-1 Expressions in Activated Macrophages. Planta Medica, 77(13), 1504-1511.

Hitner, H., Nagle, B. 2012. Pharmacology : An Introduction. 6th ed. New York : McGrawHill, p296-298.

International Association for the Study of Pain, 2017, Updated IASP Terminology. [Online]. https://www.iasppain.org/Education/Content.aspx? ItemNumb $\underline{\mathrm{er}=1698}$

Kato, E., Kubo, M., Okamoto, Y., Matsunaga, Y., Kyo, H., Suzuki, N., , Uebaba, K., Fukuyama, Y. 2018. Safety Assessment of Bangle (Zingiber purpureum Rosc.) Rhizome extract: Acute and Chronic Studies in Rats and Clinical Studies in Human. ACS Omega , 3(11), 15879-15889. 
Koontongkaew, S., Poachanukoon, O., Sireeratawong, S., Ayudhya, T.D.N., Khonsung, P., Jaijoy, K., Soawakontha, R., Chanchai, M. 2014. Safety Evaluation of Zingiber cassumunar Roxb. Rhizome Extract: Acute and Chronic Toxicity Studies in Rats. International Scholarly Research Notices, 2014.

Koparde, A.A., Magdum, C.S. 2017. Analgesic Activity of Extracts of Eulophia ochreata Lindl. and Zingiber cassumunar Roxb. in Animal Model. Int. J. Pharm. Sci. Res., 29, 1956-1962.

Manimmanakorn, N., Manimmanakorn, A., Boobphachart, D., Thuwakum, W., Laupattarakasem, W., Hamlin, M.J. 2016. Effect of Zingiber cassumunar (Plai cream) in the treatment of delayed onset muscle soreness. J. Integrat. Med., 14(2), 114-120.
Milind, P., Monu, Y. 2012. Laboratory Models for Screening Analgesics. Int. Res. J. Pharm., 4(1), 15-19.

Pudjiastuti, N.H. 1999. Penelusuran Beberapa Tanaman Obat Berkhasiat Sebagai Analgetik. Media Litbang Kes., 9(3).

Setyawati, E. 2012. Evaluasi Penggunaan Obat Analgetik Antipiretik sebagai Upaya Pengobatan Sendiri di Kelurahan Pondok Karanganom Klaten. [Skripsi]. Fakultas Farmasi. Universitas Muhammadiyah Surakarta.

Suryani, N.C., Permana, D.G.M., Jambe, A.A.G.N.A. 2016. Pengaruh Jenis Pelarut terhadap Kandungan Total Flavonoid dan Aktivitas Antioksidan Ekstrak Daun Matoa (Pometia pinnata). [Skripsi]. Universitas Udayana. 